\title{
Global expression profiling of glucose-regulated genes in pancreatic islets of spontaneously diabetic Goto-Kakizaki rats
}

\author{
Hamedeh Ghanaat-Pour, Zhen Huang, Mikael Lehtihet and Åke Sjöholm \\ Department of Internal Medicine, Karolinska Institute, Stockholm South Hospital, SE-118 83 Stockholm, Sweden \\ (Requests for offprints should be addressed to ^̊ Sjöholm; Email: ake.sjoholm @ sodersjukhuset.se)
}

\begin{abstract}
The spontaneously diabetic Goto-Kakizaki (GK) rat is frequently used as a model for human type 2 diabetes. Selective loss of glucose-sensitive insulin secretion is an early pathogenetic event in human type 2 diabetes, and such a defect also typifies islets from the GK rat. We investigated whether expression of specific glucose-regulated genes is disturbed in islets from GK rats when compared with Wistar rats. Large-scale gene expression analysis using Affymetrix microarrays and qRT-PCR measurements of mRNA species from normal and diabetic islets were performed after $48 \mathrm{~h}$ of culture at 3 or $20 \mathrm{mM}$ glucose. Of the 2020 transcripts differentially regulated in diabetic GK islets when compared with controls, 1033 were up-regulated and 987 were down-regulated. We identified significant changes in islet mRNAs involved in glucose sensing, phosphorylation, incretin action, glucocorticoid handling, ion transport, mitogenesis, and apoptosis that clearly distinguish diabetic animals from controls. Such markers may provide clues to the pathogenesis of human type 2 diabetes and may be of predictive and therapeutical value in clinical settings in efforts aiming at conferring $\beta$-cell protection against apoptosis, impaired regenerative capacity and functional suppression occurring in diabetes.
\end{abstract}

Journal of Molecular Endocrinology (2007) 39, 135-150

\section{Introduction}

In human type 2 diabetes, loss of glucose-sensitive insulin secretion is an early pathogenetic event (Malaisse 1994, Zimmet et al. 2001). The pancreatic islet $\beta$-cell serves as a unique fuel-sensing organ and is the sole producer of insulin, the key hormone in maintenance of normoglycemia, whose exocytosis is tightly controlled by the ambient plasma glucose concentrations (MacDonald 1990, Sjoholm 1998). In contrast to most other cells, in which signaling is controlled through plasma membrane receptoroperated processes, the $\beta$-cell senses subtle fluctuations in plasma glucose concentration and translates these into finely tuned changes in insulin exocytosis (MacDonald 1990, Sjoholm 1998).

As the lesions intrinsic to the $\beta$-cell causing the selective loss of glucose sensitivity remain elusive, the aim of this study was to investigate whether expression of specific genes regulated by glucose is disturbed in islets from spontaneously diabetic Goto-Kakizaki (GK) rats when compared with normoglycemic Wistar rats. The GK rat is a non-obese animal model for type 2 diabetes (Goto et al. 1976, 1988). This widely employed model exhibits diabetes-related phenotypes such as hyperglycemia, glucose intolerance, insulin resistance, and a deficient insulin response to glucose invivo and invitro. There seems to be a selective loss of glucose-sensitive insulin secretion (Kimura et al. 1982, Goto et al. 1988, Portha et al. 1991, Ostenson et al. 1993, Abdel-Halim et al. 1994) due to multiple defects in the insulin stimulus-secretion coupling. (For a review, see Portha 2005.)

Our results reveal substantial qualitative and quantitative differences in glucose-regulated islet gene expression between healthy and diabetic rats that may have implications for our understanding of the etiology and treatment of human type 2 diabetes.

\section{Materials and methods}

\section{Materials}

Collagenase A was obtained from Roche. Culture medium RPMI-1640, fetal calf serum, L-glutamine, benzylpenicillin, and streptomycin were from Flow Laboratories (Irvine, UK). Rat insulin ELISA kit was from Mercodia (Uppsala, Sweden).

\section{Islet preparation and insulin secretion}

Pancreatic islets were isolated by collagenase digestion (Sandler et al. 1987) from male diabetic GK and control Wistar rats, $\sim 3$ months old, purchased from Taconic Europe (barrier EBU 202, Bomholt site, Ry, Denmark).

DOI: 10.1677/JME-07-0002 Online version via http://www.endocrinology-journals.org 
The GK inbred model was developed by Tohoku University in 1975. Aarhus University Hospital in Denmark received stock in 1994. M\&B A/S (now Taconic Europe) received stock from Aarhus in 1997. Glucose at $3 \mathrm{mM}$ was chosen as a low-glucose comparator, non-stimulatory to both Wistar and GK islets, used in studying high glucose effects on islet gene expression in both rat strains. At the end of the culture period, batches of 500 islets were transferred to Eppendorf tubes with $0.5 \mathrm{ml}$ Trizol (Invitrogen), in which the islets were homogenized and then snapfrozen in liquid nitrogen.

Insulin secretion and islet insulin content were measured as described (Sandler et al. 1987).

\section{Monitoring of glycemia}

Non-fasting glucose levels were monitored in intracardiac blood in normal Wistar and diabetic GK rats by measurement of glucose concentration usinga glucose meter (Ascensia Contour, Bayer HealthCare), immediately after killing. The test principle used by this device is electrochemical biosensor technology using glucose oxidase. The strip uses the enzyme glucose oxidase to produce an electrical current that will stimulate a chemical reaction.

\section{Isolation of islet RNA}

Total RNA was isolated from islet tissue that was stored in Trizol at $-70{ }^{\circ} \mathrm{C}$ using standard techniques. Briefly, tissues were homogenized, chloroform was added and the tubes were vigorously mixed for $15 \mathrm{~s}$, and then allowed to sit for 2-3 min at room temperature before the tubes were centrifuged at $11900 \mathrm{~g}$ for $15 \mathrm{~min}$ at $4{ }^{\circ} \mathrm{C}$. The upper aqueous layer was removed to a new tube and isopropanol alcohol was added, the tubes were mixed, incubated at room temperature for $10 \mathrm{~min}$, and centrifuged at $11900 \mathrm{~g}$ for $10 \mathrm{~min}$ at $4{ }^{\circ} \mathrm{C}$. The pellets were washed with $75 \%$ ethanol and centrifuged at $7500 \mathrm{~g}$ for $5 \mathrm{~min}$ at $4^{\circ} \mathrm{C}$. The pellets were dried for $10 \mathrm{~min}, 100 \mu \mathrm{l}$ RNase free water was added and incubated at $50{ }^{\circ} \mathrm{C}$ for $10 \mathrm{~min}$. Isolated total RNA was further purified using an RNeasy minicolumn (Qiagen 74104) by suspending the RNA pellet in $350 \mu \mathrm{l}$ buffer RLT with 2-mercaptoethanol, followed by addition of $250 \mu \mathrm{l} 100 \%$ ethanol. The samples were applied to the column and centrifuged for $15 \mathrm{~s}$ at $\geq 8000 \mathrm{~g}$, with this step repeated with the flow-through. The column was washed twice with $500 \mu \mathrm{l}$ buffer RPE centrifugation, and then dried by centrifugation for $2 \mathrm{~min}$ at maximum speed. The bound RNA was eluted using $30 \mu \mathrm{l}$ of $65^{\circ} \mathrm{C}$ RNase-free water and centrifugation.

\section{Genome wide RNA transcript profiling}

The integrity of total RNA was confirmed by a microfluidics lab-on-a-chip analysis using a RNA 6000 Nano LabChip device and an Agilent 2100 bioanalyzer (Agilent Technologies, Palo Alto, CA, USA). The GeneChip Rat Expression Array 230A (Affymetrix Inc., Santa Clara, CA, USA) was used, which contains 15866 different probe sets interrogating primarily annotated genes. Processing of total RNA samples and GeneChip experiments were carried out essentially as recommended by Affymetrix. Ten micrograms of labeled cRNA was hybridized for $\sim 16 \mathrm{~h}$ at $45^{\circ} \mathrm{C}$ to an expression probe array. The array was then washed, stained with streptavidin-R-phycoerythrin (SAPE, Molecular Probes; Eugene, OR, USA) and the signal amplified using a biotinylated goat anti-streptavidin antibody (Vector Laboratories, Burlingame, CA, USA) followed by a final staining with SAPE. Liquid handling steps were performed using Affymetrix GeneChip Fluidics Workstation 400. The array was then scanned twice using a confocal laser scanner (GeneArray Scanner 2500; Agilent Technologies) at an excitation wavelength of $488 \mathrm{~nm}$ and emission recorded at $570 \mathrm{~nm}$, resulting in a scanned image. The scanned image was converted into numerical values of the signal intensity (Signal) and categorical expression level measurement (Absolute Call) using the Affymetrix Microarray Analysis Suite 5.0 software (MAS 5.0; Affymetrix Inc., Santa Clara, CA, USA). The software scaled the average intensity of all genes of each chip to a target intensity arbitrarily set at 150 units.

The quality control data for all microarrays used yielded values that were considered acceptable. High similarity of the scaling factors applied to each individual GeneChip array served as a first indicator of an optimal GeneChip experiment. Second, a background average value of $\sim 65$ indicated low unspecific binding. Third, a $3^{\prime}$ to $5^{\prime}$ signal ratio less or equal to 3 of the glyceraldehyde dehydrogenase gene or the $\beta$-actin gene indicated that the starting RNA had not undergone degradation and that the cDNA synthesis was optimal. Finally, the number of genes called 'present' was characteristic for the given tissue thus indicating an optimal recovery of the contained information.

To determine which genes were glucose responsive, genes were considered induced or suppressed if the average fold change was greater or equal to $1 \cdot 1$. The differentially regulated transcripts were annotated and then clustered according to functional annotation. A choice of twofold change limit of significance for the expressed transcripts could underestimate, and thereby miss, the true impact of small but biologically relevant and qualitatively important gene expression changes (Yao et al. 2004, Choe et al. 2005). Also, a twofold change, commonly used in the literature, is dubious to 
Table 1 Glycemia in non-diabetic Wistar rats and diabetic GK rats

Blood glucose $(\mathrm{mmol} / \mathrm{l})$

Non-diabetic Wistar rats

Diabetic GK rats

$8 \cdot 4 \pm 0 \cdot 3$

$17 \cdot 2 \pm 3 \cdot 1^{*}$

Non-fasting glucose levels were measured in intracardiac blood by glucose oxidase immediately after killing. Values are means \pm S.E.M. of six experiments. *Denotes $P<0.05$ for a chance difference versus nondiabetic Wistar rats using Student's $t$-test.

generate optimal results, taking into account that a factor of 2 can have different significance influenced by expression levels (Baldi \& Long 2001, Mutch et al. 2002). Nevertheless, by including a quite large number of arrays (6 and 9) we have reduced random errors when compared with similar experiments, in which fewer numbers of samples have been used. Cluster analyses were performed as described in GeneSpring (Agilent Technologies), NetAffx (Affymetrix) and other databases.

\section{cDNA synthesis}

RNA was denatured for $10 \mathrm{~min}$ at $65^{\circ} \mathrm{C}$ and immediately chilled on ice. First strand cDNA synthesis was performed in a $20 \mu \mathrm{l}$ reaction mixture containing $2 \mu \mathrm{g}$ total RNA in a solution of $10 \mu \mathrm{l}, 4 \mu \mathrm{l} 5 \times$ reverse transcriptase buffer (Invitrogen), $10 \mathrm{mM}$ deoxynucleoside triphosphate, $1 \mu \mathrm{l}$ random hexamer primers $(100 \mathrm{pmol} / \mu \mathrm{l}), 1.5 \mu \mathrm{l}$ dithiothreitol (Amersham Pharmacia Biotech; $100 \mathrm{mmol} / \mathrm{l})$, and $1 \mu \mathrm{l}$ RT1 reverse transcriptase $(200 \mathrm{U} / \mu \mathrm{l}$; Invitrogen). The reagents were mixed and incubated at $37^{\circ} \mathrm{C}$ for $45 \mathrm{~min}$. cDNA solutions were incubated for $5 \mathrm{~min}$ at $95^{\circ} \mathrm{C}$ to inactivate reverse transcriptase and then stored at $-20^{\circ} \mathrm{C}$.

\section{Quantitative real-time RT-PCR}

Expression of selected genes (Table 13) was performed from total RNA using an ABI Prism 9400 PCR machine (PE Applied Biosystems, Foster City, CA, USA). These genes were selected based on fold change in expression,
GO results, and/or potential roles in diabetes. The amount was adjusted to the endogenous reference gene $\beta$-actin. The selected genes and $\beta$-actin primers and hybridization probes (Perkin-Elmer Biosystems, Warrington, UK) were used. Probes were labeled at the $5^{\prime}$ end with the reporter dye molecule 6-carboxy-fluorescein and at the $3^{\prime}$ end with the quencher dye molecule 6-carboxytetramethylrhodamine. Results are expressed relative to $\beta$-actin with and the ratio of different groups (WH/WL, growth hormone/GL, and GL/WL). Therefore, the final value indicates an increase or decrease in mRNA for selected genes.

\section{Statistical analysis}

Results presented are derived from islets of individual rats, isolated on different days, unless otherwise stated. Means \pm s.E.M. were calculated and groups of data were compared using Student's $t$-test for paired or unpaired data. Differences were considered statistically significant when $P<0 \cdot 05$.

\section{Results}

\section{Diabetic phenotype in GK rats}

Non-fasting glucose levels monitored in intracardiac blood in normal Wistar and diabetic GK rats, as expected, were significantly higher in diabetic GK rats relative to normal Wistar rats (Table 1 ).

\section{Loss of glucose-sensitive insulin secretion in islets from GK rats}

As shown in Table 2, insulin secretion at a high glucose concentration $(20 \mathrm{mM})$, relative to $3 \mathrm{mM}$ glucose, was stimulated $4 \cdot 8$-fold in non-diabetic Wistar rat islets $(P<0 \cdot 001)$ but was not significantly augmented in islets from diabetic GK rats. In contrast, the islet insulin content was $40 \%$ higher in GK rats than in normal Wistar rats. This has been previously reported in GK islets after culture in widely different glucose concentrations (Metz et al. 1999).

Table 2 Glucose-sensitive insulin secretion in islets from non-diabetic Wistar rats and diabetic GK rats

Insulin secretion
(ng/islet per $60 \mathrm{~min})$

$3 \mathrm{mM}$ glucose

Non-diabetic Wistar rats Diabetic GK rats
$5 \cdot 56 \pm 0 \cdot 4$

$6 \cdot 67 \pm 0 \cdot 6$

\section{Insulin secretion} (ng/islet per $60 \mathrm{~min}$ )

\section{$20 \mathrm{mM}$ glucose}

$26 \cdot 4 \pm 2 \cdot 8^{*}$

$7 \cdot 8 \pm 0 \cdot 5^{\dagger}$
Islet insulin content (ng/islet)

$66 \cdot 6 \pm 3 \cdot 6$

$93 \cdot 2+2 \cdot 1^{\ddagger}$

Isolated islets were preincubated for $45 \mathrm{~min}$ at $3 \mathrm{mM}$ glucose and then exposed for $60 \mathrm{~min}$ to the indicated glucose concentrations. Insulin in incubation buffers and islet insulin contents were measured by ELISA. Values are means \pm s.E.M. of six experiments. ${ }^{\text {Denotes }} P<0 \cdot 001$ for a chance difference versus Wistar islets in low glucose, ${ }^{\dagger}$ Denotes $P<0.001$ for a chance difference versus Wistar islets in high glucose, ${ }^{\ddagger}$ denotes $P<0.001$ for a chance difference versus Wistar islets, using Student's $t$-test. 


\section{Microarray analysis of global glucose-regulated gene expression changes in islets from normal Wistar and diabetic GK rats}

To gain insight into the molecular events underlying the selective loss of glucose-sensitive insulin secretion in islets from GK rats, we performed genome-wide oligonucleotide microarray analyses of glucose-stimulated islets from normal Wistar and diabetic GK rats. Of the 15866 transcripts analyzed by microarray, 2020 were differentiallyexpressed by comparing samples prepared from diabetic GK rat islets and normal Wistar rats, cultured in either $3 \mathrm{mM}$ or $20 \mathrm{mM}$ glucose.
The functional groupingof the differentially expressed transcripts shows that 1033 of these 2020 transcripts were up-regulated and 987 were down-regulated. A great proportion of these glucose responsive genes and expressed sequence tags are involved in metabolism, signaling, transport, apoptosis, transcription, proliferation, and immune response (Fig. 1). The experimental setup of the current work, two days in vitro culture, was deliberately designed in an attempt to minimize remaining influence of in vivo glucotoxicity or other manifestations of the diabetic state on islet function. However, we cannot completely exclude the possibility of remaining minor influences of in vivo glucotoxicity

B
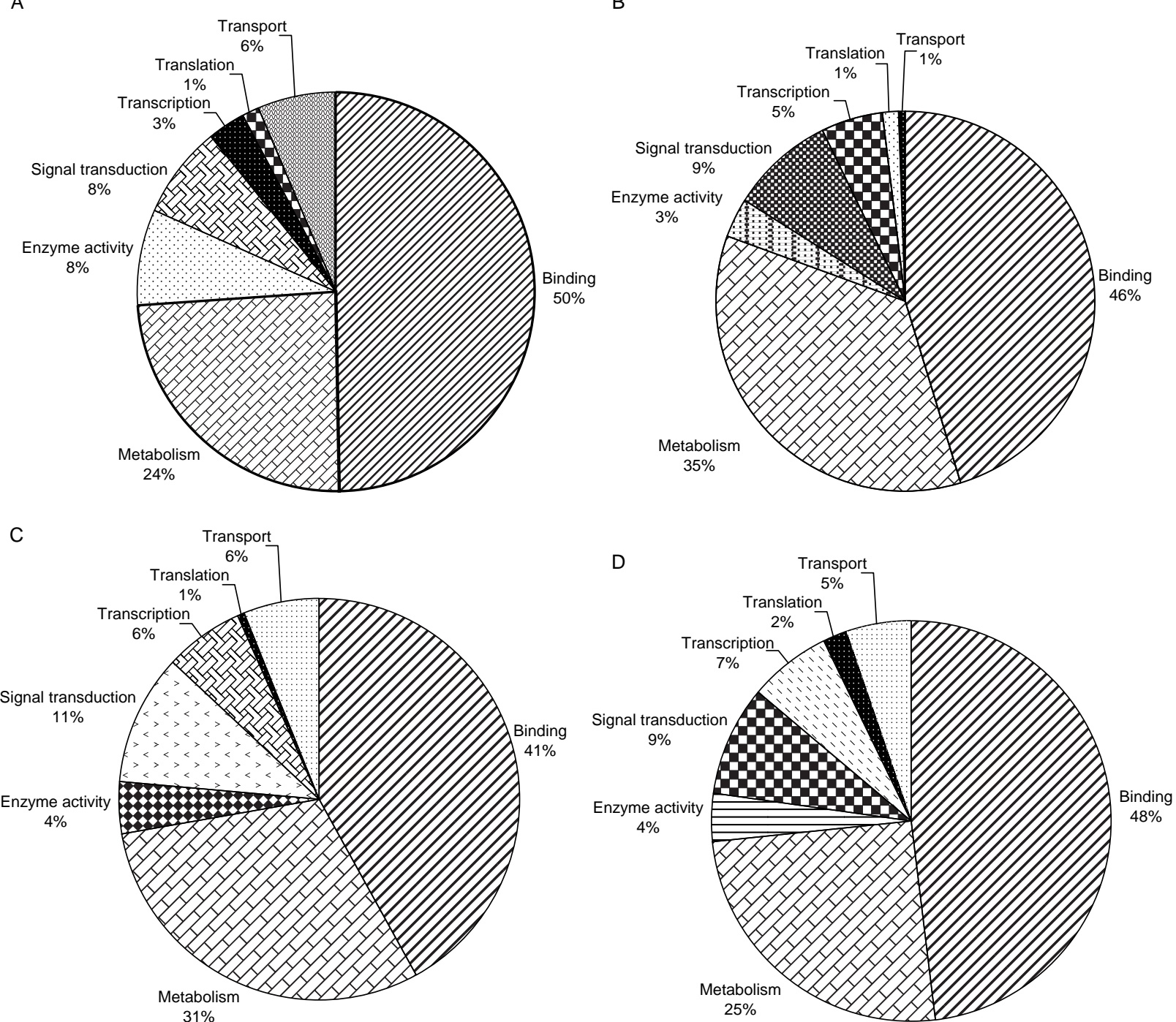

Figure 1 (A) Functional clusters of genes up-regulated by high glucose in diabetic GK rats vs. non-diabetic Wistar rats. (B) Functional clusters of genes up-regulated by low glucose in diabetic GK rats versus non-diabetic Wistar rats. (C) Functional clusters of genes down-regulated by high glucose in diabetic GK rats versus non-diabetic Wistar rats. (D) Functional clusters of genes down-regulated by low glucose in diabetic GK rats versus non-diabetic Wistar rats. 
Table 3 Islet transcripts up-regulated by high versus low glucose in diabetic GK rats

Accession no.

Gene name

Function
Transport

\begin{tabular}{|c|c|}
\hline & U44897 \\
\hline & NM_053685 \\
\hline & NM_013186 \\
\hline & X92069 \\
\hline & AA685184 \\
\hline & AW532988 \\
\hline & NM_012878 \\
\hline & Al547447 \\
\hline & NM_012663 \\
\hline & M83̄요 \\
\hline & AA943569 \\
\hline Metabolism & NM_031344 \\
\hline & AA $\overline{848820}$ \\
\hline & $\mathrm{Bl} 277460$ \\
\hline & Y11321 \\
\hline & L23863 \\
\hline Apoptosis & Al639457 \\
\hline & AW143805 \\
\hline & AW533214 \\
\hline Signal transduction & NM_012714 \\
\hline & NM_053777 \\
\hline & X92069 \\
\hline & Al234096 \\
\hline & AA799421 \\
\hline & NM_053856 \\
\hline & $\mathrm{NM}^{-} 133522$ \\
\hline Development & NM_019128 \\
\hline & NM_012630 \\
\hline & AW'143798 \\
\hline Catalytic activity & AF106659 \\
\hline & $\begin{array}{l}\text { L07578 } \\
\text { NM } 019349\end{array}$ \\
\hline
\end{tabular}
(Abcc8)

(Kcnj11) 1 (Kcnb1) 3 (Kcnc3)
ATP-binding cassette, sub-family C (CFTR/MRP), member 8

Potassium inwardly rectifying channel, subfamily J, member $11 \quad 1.5$

Hyperpolarization-activated cyclic nucleotide-gated potassium channel 3 (Hcn3)

Potassium voltage gated channel, Shab-related subfamily, member

Purinergic receptor P2X, ligand-gated ion channel, 5 (P2rx5)

Sodium channel, voltage-gated, type III, beta (Scn3b)

Hyperpolarization activated cyclic nucleotide-gated potassium channel 2 (Hcn2)

Surfactant associated protein D (Sftpd)

Potassium voltage gated channel, Shaw-related subfamily, member

Vesicle-associated membrane protein 2 (Vamp2)

RAB3D, member RAS oncogene family (Rab3d)

Synaptotagmin 1 (Syt1)

Fatty acid desaturase 2 (Fads2)

15-hydroxyprostaglandin dehydrogenase (Hpgd)

Phosphoenolpyruvate carboxykinase 1 (Pck1)

Forkhead box E1 (thyroid transcription factor 2) (Foxe1)

POU domain, class 2, transcription factor 3 (Pou2f3)

GTP cyclohydrolase 1 (Gch)

Guanine nucleotide binding protein, alpha q polypeptide (Gnaq)

Rabaptin 5 (Rabep1)

Gastric inhibitory polypeptide receptor (Gipr)

Mitogen activated protein kinase 8 interacting protein (Mapk8ip)

Purinergic receptor P2X, ligand-gated ion channel, 5 (P2rx5)

Protein kinase, cAMP dependent regulatory, type I, alpha (Prkar1a)

Protein kinase $\mathrm{C}$, epsilon (Prkce)

Secretogranin III (Scg3)

Somatostatin receptor 3

Internexin, alpha (Inexa)

Prolactin receptor (Prlr)

Cyclin D1 (Ccnd1)

Ubiquitin specific protease 2 (Usp2)

Casein kinase 1, delta (Csnk1d)

Serine/threonine kinase 2 (Slk)
Fold change

\section{$\cdot 5$}

$1 \cdot 4$

$1 \cdot 8$

$1 \cdot 6$

$1 \cdot 5$

$1 \cdot 4$

1.5

$1 \cdot 8$

$1 \cdot 6$

$1 \cdot 6$

$1 \cdot 3$

$1 \cdot 4$

$1 \cdot 7$

1.4

1.5

1.5

1.5

$1 \cdot 4$

$1 \cdot 3$

$2 \cdot 3$

$1 \cdot 2$

$1 \cdot 6$

$1 \cdot 1$

$1 \cdot 2$

$1 \cdot 7$

$1 \cdot 3$

$1 \cdot 9$

$1 \cdot 3$

$1 \cdot 2$

$1 \cdot 3$

$1 \cdot 4$

1.5 or other manifestations of the diabetic state on islet gene expression.

Detailed descriptions of a selection of the differentially expressed transcripts, classified according to function and average fold change, are listed in Tables 3-12.

\section{Differential expression of a subset of genes confirmed with qRT-PCR}

In order to validate the qualitative changes in gene expression revealed by the microarray analyses, the expression of selected genes was also confirmed by realtime qRT-PCR. The same expression pattern as that identified by the microarray analyses was found by realtime qRT-PCR for $11 \beta$-hydroxysteroid dehydrogenase type 1 (11ß-HSD-1) (NM_017080), serum- and glucocorticoid-inducible kinase 1 (SGK-1) (NM_019232), insulin-like growth factor binding protein 3 (IGFBP-3) (NM_012588), and ApoE (J02582; Table 13), whose expression levels were all significantly changed $(P<0 \cdot 05)$. Insulin-2 was not captured as differentially expressed in the microarray analyses, using the selected cut off values, but was significantly more up-regulated by high glucose in islets from normal Wistar than from diabetic GK rats in the qRT-PCR analysis. Microarrays seem to offer a smaller dynamic range when compared with other platforms. This means that changes observed in other platforms may not be accurately reflected by microarray expression levels. The poor correlation between microarray and qRT-PCR may be due to the inherent sensitivity limits of a PCR-based approach (qRT-PCR) in comparison with a hybridization-based approach 
Table 4 Islet transcripts down-regulated by high versus low glucose in diabetic GK rats

Accession no.

Gene name

Ectonucleotide pyrophosphatase/phosphodiesterase 3 (Enpp3)

Glycoprotein (transmembrane) $\mathrm{nmb}$ (Gpnmb)

Apolipoprotein B editing complex 1 (Apobec1)

Matrix metallopeptidase 12 (Mmp12)

Cathepsin Z (Ctsz)

Cathepsin S (cathepsin S)

Lysozyme (Lyz)

Serum- and glucocorticoid-inducible kinase 1 (Sgk)

B-cell leukemia/lymphoma 2 related protein A1 (Bcl2a1)

Heme oxygenase (decycling) 1 (Hmox 1 )

Apolipoprotein E (Apoe)

$\mathrm{BH} 3$ interacting domain death agonist (Bid)

$\mathrm{Bcl} 2$-associated death promoter (Bad)

Protein kinase $\mathrm{C}$, delta (Prkcd)

Complement component 5, receptor 1 (C5r1)

Ectonucleoside triphosphate diphosphohydrolase 1 (Entpd1)

Complement component 3a receptor 1 (C3ar1)

Hemopoietic cell kinase (Hck)

Lymphocyte cytosolic protein 2 (Lcp2)

Interleukin 2 receptor, gamma (severe combined immunodeficiency) (II2rg)

Catalytic activity $\quad$ NM_031811 NM_022592

AF154349

$\mathrm{Al} 232474$

Al409046

Response to stimulus NM_053843

Al17 1966

$\mathrm{BI} 301490$

NM_017196

$\mathrm{BI} \mathbf{8} 2932$
Transaldolase 1 (Taldo1)

Transketolase (Tkt)

Legumain (Lgmn)

Cathepsin L (Ctsl)

Cathepsin C (Ctsc)

Fc gamma receptor II beta

Major histocompatibility complex, class II, DM beta

Major histocompatibility complex, class II, DM alpha

Allograft inflammatory factor 1 (Aif1)

Lymphocyte antigen 68 (C1qr1)
Fold change

$1 \cdot 6$

$1 \cdot 6$

$2 \cdot 5$

$2 \cdot 5$

2.5

2.5

1.6

2

$1 \cdot 3$

2

$1 \cdot 1$

$1 \cdot 3$

2

$1 \cdot 6$

4

2

$1 \cdot 6$

$1 \cdot 4$

$1 \cdot 3$

$1 \cdot 4$

$1 \cdot 3$

$1 \cdot 4$

2

$1 \cdot 6$

2.5

$1 \cdot 6$ (microarray). Also, differences in sequence, their placement along the target transcript and feature design may all contribute to discrepancies in results obtained by the two methods used. All these reasons could explain why the insulin-2 gene was not captured as differently expressed in the microarray data but in qRT-PCR analysis.

\section{Discussion}

In human type 2 diabetes, loss of glucose-sensitive insulin secretion is an important pathogenetic event (Malaisse 1994, Zimmet et al. 2001). The change in $\beta$-cell phenotype involves a selective loss of glucosestimulated insulin secretion even in the very earliest stages of disease progression. The molecular basis for this functional defect remains elusive, but also constitutes an inviting target for attempts to intervene against $\beta$-cell failure and outbreak of type 2 diabetes. In the present work, we have attempted to identify such targets using genome-wide transcription profiling of glucose-regulated genes in isolated pancreatic islets from normal Wistar rats and diabetic GK rats. In this substrain of GK rats of this age, $\beta$-cell density and relative volume of islet endocrine cells are not different from age- and sex-matched Wistar rats (Ohneda et al. 1993, Guenifi et al. 1995). Our results reveal substantial qualitative and quantitative differences in glucoseregulated islet gene expression between healthy and diabetic rats that may have implications for our understanding of the etiology of human type 2 diabetes.

Key elements in steroid metabolism were abnormally expressed in diabetic GK islets (Table 7); e.g. 11ß-HSD-1 (NM_017080; Davani et al. 2000, Duplomb et al. 2004, Ortsater et al. 2005) and SGK-1 (NM_019232; Ullrich et al. 2005) which are important effectors of glucocorticoid handling in the $\beta$-cell and known to influence glucosesensitive insulin secretion. In rodents, 11ß-HSD-1 (NM_017080) converts inactive 11-dehydrocorticosterone into active corticosterone. The mRNA and activity of $11 \beta$ HSD-1 (NM_017080) have been shown to be up-regulated in islets from hyperglycemic mice (Davani et al. 2000, Ortsater et al. 2005) and the Zucker Diabetic Fatty rat (Duplomb et al. 2004) when compared with their normoglycemic counterparts. The $\beta$ cell may be extra susceptible to glucocorticoid excess, since both iatrogenic Cushing syndrome and steroid-induced diabetes in animal 
Table 5 Islet transcripts up-regulated by high glucose in diabetic GK rats versus high glucose in non-diabetic Wistar rats

Accession no.

Gene name

Transport

Al547447

Al009597

NM_017049

U39555

AA945624

BG373779

BI296640

Metabolism

NM_052798

BM386917

AI229183

NM_012692

BI295900

NM_053864

NM_057137

Signal transduction NM_017139

Al233208

Al234096

Cell cycle

BE097028

U95920

F-box only protein 32 (Fbxo32)

Deiodinase, iodothyronine, type II Solute carrier family 25 (mitochondrial carrier, brain), member 14 (Dio2 Slc25a14)

Potassium voltage gated channel, Shaw-related subfamily, member 3 (Kcnc3)

FXYD domain-containing ion transport regulator 3

Solute carrier family 4, member 3 (Slc4a3)

Solute carrier family 1 (neuronal/epithelial high affinity glutamate

transporter, system Xag), member 1 (Slc1a1)

$\mathrm{NAD}(\mathrm{P}) \mathrm{H}$ dehydrogenase, quinone 2

Desmuslin (Dmn)

Epsin 2 (Epn2)

Zinc finger protein 354A (Znf354a)

Inosine triphosphatase (nucleoside triphosphate pyrophosphatase) (Itpa)

DnaJ (Hsp40) homolog, subfamily A, member 2 (Dnaja2)

Cytochrome P450 IIA1 (hepatic steroid hydroxylase IIA1) gene

(Cyp2a1)

Dihydrolipoamide S-acetyltransferase (E2 component of pyruvate

dehydrogenase complex; Dlat)

Valosin-containing protein (Vcp)

Phenylalkylamine $\mathrm{Ca}^{2+}$ antagonist (emopamil) binding protein (Ebp)

Preproenkephalin, related sequence (Penk-rs)

Calcium regulated heat stable protein 1 (Carhsp1)

Protein kinase, cAMP dependent regulatory, type I, alpha (Prkar1a)

Phospholipase $\mathrm{C}$, beta 1 (Plcb1)

Pericentriolar material 1 (Pcm1)
Fold change

$1 \cdot 3$

$1 \cdot 3$

$1 \cdot 5$

$1 \cdot 4$

$1 \cdot 2$

$1 \cdot 2$

$1 \cdot 2$

$1 \cdot 6$

$1 \cdot 2$

$1 \cdot 4$

$1 \cdot 3$

$1 \cdot 4$

$1 \cdot 6$

$1 \cdot 3$

$1 \cdot 1$

$1 \cdot 2$

$1 \cdot 5$

$1 \cdot 2$

$1 \cdot 1$

$1 \cdot 1$

$1 \cdot 2$ models are associated with loss of glucose-stimulated insulin secretion, and steroid immunosuppressive treatment adversely affects islet transplantation outcome (Shapiro et al. 2000). Glucocorticoids decrease insulin gene expression (Philippe et al. 1992), increase glucose-6phosphatase, phosphoenolpyruvate carboxykinase (PEPCK) activity and glucose cycling (Ling et al. 1998, Davani et al. 2004), and induce $\beta$-cell apoptosis (Weinhaus et al. 2000), all events occurring in GK rat islets (Portha 2005). Since the human insulin gene contains glucocorticoid-sensitive transcriptional elements (Fernandez-Mejia et al. 1999), it may be susceptible to islet overproduction of glucocorticoids. Our findings may also be of therapeutical significance, given the attention currently paid to pharmacological 11 $\beta$-HSD-1 inhibitors in clinical trials against type 2 diabetes (Seckl \& Walker 2001).

$\beta$-cell susceptibility to glucocorticoids may also be relevant in the natural unfolding of diabetes, since mice overexpressing the glucocorticoid receptor restricted to the $\beta$-cell develop early $\beta$-cell failure, glucose intolerance and later in life overt diabetes (Ling et al. 1998, Davani et al. 2004). Humans with impaired $\beta$-cell function (low insulin responders) are predisposed to become overtly diabetic during glucocorticoid therapy (Wajngot et al. 1992).

Another gene involved in transducing glucocorticoid effects, which was found to be abnormally regulated by glucose in diabetic GK islets, is SGK-1 (NM_019232; Table 7). SGK-1, whose expression is increased by glucocorticoids (Ullrich et al. 2005), appears to be instrumental in directly regulating insulin secretion negatively, since the suppression of glucose-sensitive insulin secretion normally evoked by dexamethasone was lost in islets from SGK-1 (NM_019232) knockout mice (Ullrich et al. 2005). In islets, SGK-1 (NM_019232) up-regulates the activity of voltage-activated $\mathrm{K}^{+}$ channels $\left(K_{\mathrm{v}}\right)$ thereby reducing $\mathrm{Ca}^{2+}$ entry and insulin secretion (Ullrich et al. 2005). Since intracellular $\mathrm{Ca}^{2+}$ handling appears intrinsically disturbed in GK rat islets (Kato et al. 1996, Varadi et al. 1996), and can be deranged by glucocorticoid treatment (Lambillotte et al. 1997), it seems that SGK-1 (NM_019232) also may be of both pathogenetic and therapeutical interest in type 2 diabetes and steroid diabetes.

As for the differential expression of $K_{\mathrm{v}}$ in our present study, it was found that the delayed rectifier $K_{\mathrm{v}} 2 \cdot 1$ (Kcnb1; NM_013186) subtype was preferentially up-regulated by high glucose in islets from diabetic GK rats (Table 3). Since this is the dominant $K_{\mathrm{v}}$ in rodent and human islets, contributing to some $85 \%$ of their steady-state outward current, it negatively regulates $\mathrm{Ca}^{2+}$ dynamics and insulin secretion (MacDonald \& Wheeler 2003). Hence, the up-regulation of $K_{\mathrm{v}} 2 \cdot 1$ 
Table 6 Islet transcripts down-regulated by high glucose in diabetic GK rats versus high glucose in non-diabetic Wistar rats

\begin{tabular}{|c|c|c|c|}
\hline & Accession no & Gene name & Fold change \\
\hline \multicolumn{4}{|l|}{ Function } \\
\hline \multirow[t]{3}{*}{ Transport } & NM_022534 & Transcobalamin 2 (Tcn2) & $1 \cdot 2$ \\
\hline & NM_030834 & Monocarboxylate transporter (Slc16a3) & $1 \cdot 2$ \\
\hline & NM_017288 & Sodium channel, voltage-gated, type I, beta polypeptide (Scn1b) & $1 \cdot 2$ \\
\hline \multirow{11}{*}{ Metabolism } & D87247 & 6-phosphofructo-2-kinase/fructose-2,6-biphosphatase 3 (Pfkfb3) & $1 \cdot 4$ \\
\hline & $\mathrm{Bl} 294137$ & Hexokinase 2 (Hk2) & $1 \cdot 4$ \\
\hline & NM_012497 & Aldolase C, fructose-biphosphate (Aldoc) & $1 \cdot 6$ \\
\hline & NM_013190 & Phosphofructokinase, liver, B-type (Pfkl) & $1 \cdot 2$ \\
\hline & $\mathrm{BI} 283882$ & Glucose phosphate isomerase (Gpi) & $1 \cdot 2$ \\
\hline & NM_022268 & Liver glycogen phosphorylase (Pygl) & $1 \cdot \overline{6}$ \\
\hline & AY081195 & Monoglyceride lipase (Mgll) & $1 \cdot 4$ \\
\hline & AA849399 & Cathepsin Z (Ctsz) & $1 \cdot 6$ \\
\hline & AB020480 & SNF1-like kinase (Snf1lk) & $1 \cdot 4$ \\
\hline & NM_019236 & Hairy and enhancer of split 2 (Drosophila) (Hes2) & $1 \cdot 4$ \\
\hline & NM_022627 & $\begin{array}{l}\text { Protein kinase, AMP-activated, beta } 2 \text { non-catalytic subunit } \\
\text { (Prkab2) }\end{array}$ & $1 \cdot 4$ \\
\hline Apoptosis & NM_053420 & BCL2/adenovirus E1B 19 kDa-interacting protein 3 (Bnip3) & $1 \cdot 4$ \\
\hline \multirow[t]{6}{*}{ Signal transduction } & NM_012488 & Alpha-2-macroglobulin (A2m) & $1 \cdot 6$ \\
\hline & NM_053826 & Pyruvate dehydrogenase kinase 1 (Pdk1) & $1 \cdot 4$ \\
\hline & NM_022441 & Activin A receptor type II-like 1 (Acvrl1) & $1 \cdot 4$ \\
\hline & AB020967 & Tribbles homolog 3 (Drosophila; Trib3) & $1 \cdot 4$ \\
\hline & Al178808 & $\begin{array}{l}\text { Interleukin } 2 \text { receptor, gamma (severe combined immunodeficiency; } \\
\text { II2rg) }\end{array}$ & $1 \cdot 4$ \\
\hline & NM_013085 & Plasminogen activator, urokinase (Plau) & $1 \cdot 6$ \\
\hline \multirow[t]{5}{*}{ Development } & NM_012588 & Insulin-like growth factor binding protein 3 (Igfbp3) & $1 \cdot 6$ \\
\hline & NM_019370 & Ectonucleotide pyrophosphatase/phosphodiesterase 3 (Enpp3) & $1 \cdot 4$ \\
\hline & NM_133298 & Glycoprotein (transmembrane) nmb (Gpnmb) & $1 \cdot 6$ \\
\hline & NM_019329 & Contactin 3 (Cntn3) & $1 \cdot 4$ \\
\hline & NM_012580 & Heme oxygenase (decycling) 1 (Hmox1) & $1 \cdot 4$ \\
\hline \multirow[t]{3}{*}{ Response to stimulus } & NM_031051 & Macrophage migration inhibitory factor (Mif) & $1 \cdot 1$ \\
\hline & $\mathrm{BI} 284218$ & $\begin{array}{l}\text { Solute carrier family } 2 \text { (facilitated glucose transporter), member } 1 \\
\text { (Slc2a1) }\end{array}$ & $1 \cdot 4$ \\
\hline & $\mathrm{Bl} 282122$ & EGL nine homolog 1 (C. elegans; Egln1) & $1 \cdot 4$ \\
\hline \multirow[t]{2}{*}{ Cell adhesion } & NM_133298 & Glycoprotein (transmembrane) nmb (Gpnmb) & $1 \cdot 6$ \\
\hline & NM_017190 & Myelin-associated glycoprotein (Mag) & $1 \cdot 4$ \\
\hline Cell-cell signaling & Al009159 & Synapsin III (Syn3) & $1 \cdot 6$ \\
\hline Homeostasis & $\mathrm{Bl} 277505$ & Phosphoglucomutase 1 (Pgm1) & $1 \cdot 4$ \\
\hline
\end{tabular}

(NM_013186) in GK islets is likely to contribute to a more hyperpolarized state of the diabetic $\beta$-cells, thereby suppressing glucose-stimulated insulin secretion. Since this is exactly what typifies the GK rat islets (Table 2; Hughes et al. 1998), it is possible that $K_{\mathrm{v}} 2 \cdot 1$ overexpression is an intrinsic $\beta$-cell defect that contributes to its loss of glucose sensitivity in the GK rat. To our knowledge, this is the first report describing $K_{\mathrm{v}} 2 \cdot 1$ (Kcnb1; NM_013186) overexpression in diabetic islets and makes $K_{\mathrm{v}} 2 \cdot 1$ an attractive target for antidiabetic drugs.

Among other ion transporters of strong pathophysiological and therapeutic interest that were aberrantly expressed in GK rat islets, were the sulfonylurea receptor (SUR1/Abcc8 (AB052294)) and its associated inwardly rectifying ATP-sensitive $\mathrm{K}^{+}$channel (Kir6.2/Kcnj11 (U44897)). Both were found to be up-regulated by high glucose in GK rat islets (Table 3) but not in Wistar, again features that would be expected to contribute to attenuation of glucose-sensitive insulin secretion in GK rat islets. Consistent with such a scenario are also previous reports describing that nonsense mutations in the SUR1/Abcc8 (AB052294) or Kir6.2/Kcnj11 (U44897) genes result in hyperinsulinism and hypoglycemia due to unregulated oversecretion of insulin (Nestorowicz et al. 1997, Verkarre et al. 1998).

Among other genes dysregulated in GK islets, we found up-regulation of the membrane receptor CD36 (NM_031561; Table 11). This facilitates the major fraction of long-chain FA uptake in a variety of tissues, including the $\beta$-cell (Noushmehr et al. 2005). In human $\beta$-cells, CD36 was found to specifically mediate the inhibitory effects of FA on insulin secretion (Noushmehr et al. 2005). Interestingly, CD36 (NM_031561) was also recently found to be up-regulated by high glucose and associated with accelerated atherosclerosis in humans (Griffin et al. 2001) thus forming a possible link between diabetes and atherosclerosis. CD36 (NM_031561) functions as a transporter for oxidized 
Table 7 Islet transcripts up-regulated by low glucose in diabetic GK rats versus low glucose in non-diabetic Wistar rats

Accession no

Gene name

BM392280

BF417032

NM_023101

NM_023950

NM_031718

Metabolism

NM_134334

NM_031973

NM_012980

NM_031811

NM 057188

NM_031095

BG673255

D00252

U32497

AA799614

$\begin{array}{ll}\text { Apoptosis } & \text { J02582 } \\ & \text { BM986220 } \\ & \text { AF279911 } \\ & \text { M15481 } \\ & \text { AA998057 } \\ & \text { NM_019232 } \\ & \text { NM_024134 } \\ \text { Signal transduction } & \text { NM_054011 } \\ \text { Development } & \text { BE111972 } \\ & \\ \text { Response to stimulus } & \text { NM_133380 } \\ & \text { BI301490 } \\ \text { Homeostasis } & \text { Al137137 } \\ \text { Hon050011 }\end{array}$
(Slc29a3) (yeast; Vti1a)
Solute carrier family 29 (nucleoside transporters), member 3

Transferrin receptor (Tfrc)

Vesicle transport through interaction with t-SNAREs homolog $1 \mathrm{~A}$

RAB7, member RAS oncogene family (Rab7)

RAB2, member RAS oncogene family (Rab2)

Cathepsin D (Ctsd)

Dipeptidylpeptidase 7 (Dpp7)

Matrix metalloproteinase 11 (Mmp11)

Transaldolase 1 (Taldo1)

Guanosine monophosphate reductase (Gmpr)

Renin binding protein (Renbp)

Phosphate cytidylyltransferase 1, choline, alpha isoform (Pcyt1a)

Glutamate oxaloacetate transaminase 1 (Got1)

Purinergic receptor P2X, ligand-gated ion channel 4 (P2rx4)

Sirtuin (silent mating type information regulation 2 homolog) 2 (S. cerevisiae; Sirt2)

Apolipoprotein E (Apoe)

Amyloid beta (A4) precursor protein (App)

$\mathrm{Bcl} 2$-associated death promoter (Bad)

Insulin-like growth factor 1 (Igf1)

V-akt murine thymoma viral oncogene homolog 1 (Akt1)

Serum- and glucocorticoid-inducible kinase 1 (Sgk)

DNA-damage inducible transcript 3 (Ddit3)

SH3-domain binding protein 5 (BTK-associated; Sh3bp5)

Transforming growth factor, beta receptor 1 (Tgfbr1)

$11 \beta$-hydroxysteroid dehydrogenase type 1 (Hsd11b1)

Interleukin 4 receptor (II4r)

Major histocompatibility complex, class II, DM alpha

Lymphocyte protein tyrosine kinase (Lck)

V-maf musculoaponeurotic fibrosarcoma oncogene family, protein G (avian; Mafg)
Fold change

$1 \cdot 5$

$1 \cdot 3$

$1 \cdot 3$

$1 \cdot 2$

$1 \cdot 1$

$1 \cdot 6$

$1 \cdot 4$

$1 \cdot 6$

$1 \cdot 4$

1.5

$1 \cdot 4$

$1 \cdot 4$

$1 \cdot 4$

$1 \cdot 4$

$1 \cdot 3$

$2 \cdot 4$

$1 \cdot 1$

1.2

2.5

$1 \cdot 2$

$1 \cdot 8$

$1 \cdot 4$

$1 \cdot 4$

1.5

1.5

$1 \cdot 4$

1.9

$1 \cdot 2$

$1 \cdot 2$
LDL-cholesterol (Okajima et al. 2005). These findings, in conjunction with previous reports showing that oxidized LDL-cholesterol suppresses insulin gene transcription and promotes $\beta$-cell death (Cnop et al. 2002, Okajima et al. 2005), raises the possibility that CD36 (NM_031561) up-regulation might be involved in $\beta$-cell dysfunction. Although GK rats are not hyperlipidemic (Zhou et al. 1995), the increased CD36 (NM_031561) expression may promote functional suppression and possibly lipoapoptosis as part of glucolipotoxicity (Koyama et al. 1998, Prentki et al. 2002). In accordance with such a scenario, previous reports indicate that endogenous FA catabolism is greater in GK islets than in Wistar islets (Sener et al. 1993), and that high-fat feeding impedes glucosesensitive insulin secretion in islets from GK rats while not affecting Wistar islets (Briaud et al. 2002).

Several genes regulating glucose metabolism were also found to be dysregulated in GK rat islets. In Wistar islets, several transcripts encoding glycolytic enzymes were up-regulated by glucose (Table 9), thus confirming findings in islet cell lines (Roche et al. 1997) indicating an intact islet adaptive response to hyperglycemia. In contrast, these glycolytic genes were down-regulated by high glucose in diabetic islets (Table 6), suggesting impaired glycolytic signaling that may contribute to $\beta$-cell failure in GK rats (Mertz et al. 1996). These genes were also found to be down-regulated in islets from patients with type 2 diabetes (Gunton et al. 2005). Impaired glucose metabolism might negatively impact other islet functions than solely secretion, such as insulin gene expression and $\beta$-cell proliferation, both events strongly induced by glucose (Nielsen et al. 1985, Sjoholm 1997). Impaired insulin gene expression and $\beta$-cell proliferation characterize not only GK islets (Portha 2005) but also islets from type 2 diabetic humans (Butler et al. 2003, Del Guerra et al. 2005). (PEPCK/PCK1; BI277460) was induced by high glucose in diabetic GK islets (Table 3 ). This gluconeogenic enzyme is normally not expressed in islets (MacDonald et al. 1992), thus effectively preventing gluconeogenesis through conversion of oxaloacetate to phosphoenolpyruvate. Its induction by high glucose (and endogenous glucocorticoids) in diabetic islets may contribute to glucose futile cycling, consuming ATP in 
Table 8 Islet transcripts down-regulated by low glucose in diabetic GK rats versus low glucose in non-diabetic Wistar rats

\begin{tabular}{|c|c|c|c|}
\hline & Accession no & Gene name & Fold change \\
\hline \multicolumn{4}{|l|}{ Function } \\
\hline \multirow[t]{4}{*}{ Transport } & AA944965 & Group specific component (Gc) & $1 \cdot 4$ \\
\hline & NM_053311 & ATPase, $\mathrm{Ca}++$ transporting, plasma membrane 1 (Atp2b1) & $1 \cdot 1$ \\
\hline & L06821 & Nucleoporin 153kD (Nup153) & $1 \cdot 4$ \\
\hline & BG381386 & Huntingtin interacting protein 1 related (Hip $1 \mathrm{r}$ ) & $1 \cdot 4$ \\
\hline \multirow{5}{*}{ Metabolism } & NM_031344 & Fatty acid desaturase 2 (Fads2) & $1 \cdot 4$ \\
\hline & U03389 & Prostaglandin-endoperoxide synthase 2 (Ptgs2) & 2 \\
\hline & NM_031976 & $\begin{array}{l}\text { Protein kinase, AMP-activated, beta } 1 \text { non-catalytic subunit } \\
\text { (Prkab1) }\end{array}$ & $1 \cdot 3$ \\
\hline & AF332142 & Chloride ion pump-associated 55 kDa protein (Pcyox1) & $1 \cdot 4$ \\
\hline & AF221622 & Thyroglobulin $(\mathrm{Tg})$ & $1 \cdot 4$ \\
\hline \multirow[t]{7}{*}{ Signal transduction } & NM_133317 & Transducer of ERBB2, 1 (Tob1) & $1 \cdot 4$ \\
\hline & NM_032069 & Glutamate receptor interacting protein 1 (Grip1) & $1 \cdot 4$ \\
\hline & NM_030851 & Bradykinin receptor B1 (Bdkrb1) & $1 \cdot 4$ \\
\hline & AF026530 & Stathmin-like 4 (Stmn4) & $1 \cdot 6$ \\
\hline & Al177031 & ER transmembrane protein Dri 42 (Ppap2b) & $1 \cdot 4$ \\
\hline & AW143805 & Guanine nucleotide binding protein, alpha q polypeptide (Gnaq) & $1 \cdot 6$ \\
\hline & & Interleukin 2 receptor, beta chain (II2rb) & $1 \cdot 4$ \\
\hline \multirow[t]{3}{*}{ Cell cycle } & NM_017066 & Pleiotrophin (Ptn) & $1 \cdot 4$ \\
\hline & BE108911 & DNA primase, p49 subunit & $1 \cdot 4$ \\
\hline & X75207 & Cyclin D1 (Ccnd1) & $1 \cdot 2$ \\
\hline \multirow[t]{2}{*}{ Development } & NM_012676 & Troponin T2, cardiac (Tnnt2) & $1 \cdot 4$ \\
\hline & NM_017066 & Pleiotrophin (Ptn) & $1 \cdot 4$ \\
\hline
\end{tabular}

these islets (Ostenson et al. 1993). Interestingly, PEPCK/ PCK1 (BI277460) was recently proposed as a candidate gene for human type 2 diabetes (Cao et al. 2004).

Several important effectors of protein phosphorylation and exocytosis were also dysregulated in GK islets. The AMP-activated protein kinase (AMPK; Prkab2, Prkab1; NM_022627, NM_031976), proposed as a novel $\beta$-cell glucose sensor (da Silva Xavier et al. 2003, Tsuboi et al. 2003, Leclerc \& Rutter 2004) was down-regulated in diabetic islets (Table 12) consistent with reports of reduced AMPK (Prkab2, Prkab1; NM_022627, NM_031976) activity in human islets from type 2 diabetic subjects (Del Guerra et al. 2005). Protein kinase C (PKC) isoforms were also differentially expressed; PKC- $\delta /$ Prkcd (NM_133307) being down-regulated by high glucose in GK islets (Table 4), whereas PKC- $\varepsilon$ /Prkce (AA799421) showed the opposite response (Table 3). PKC- $\delta /$ Prkcd (NM_133307) has previously been linked to $\beta$-cell apoptosis (Carpenter et al. 2002, Eitel et al. 2003), so its suppression in GKislets (recently confirmed; Warwar et al. 2006) could represent a defence effort against $\beta$-cell demise. Conversely, the up-regulation in GK islets of PKC- $\varepsilon /$ Prkce (AA799421), known to be required for short-term insulin secretion (Hoy et al. 2003; Mendez et al. 2003), may represent an effort to compensate for the impaired insulin secretion by the diabetic islets. Phospholipase C $\beta 1$ (PLC- $\beta 1$; BE097028) was up-regulated by high glucose in GK (but not Wistar) islets (Table 5), an event that could contribute to impaired insulin secretion in GK islets since overexpression of PLC- $\beta 1$ (BE097028) in insulin-secreting cells reportedly inhibits insulin release (Ishihara et al. 1999). Somatostatin receptor subtype 3, whose expression has been reported in normal rat islets (Ludvigsen et al. 2004), was found to be up-regulated by high glucose in diabetic GK islets (Table 3). This could indicate an enhanced sensitivity of diabetic islets to the suppressive influences of paracrine somatostatin on insulin secretion.

Several critical factors controlling cell proliferation and apoptosis were also aberrantly expressed in GK islets. Cyclin D1 (Ccnd1; X75207), driving cells from G1 into cell cycle S-phase, was down-regulated in diabetic 
Table 9 Islet transcripts up-regulated by high versus low glucose in non-diabetic Wistar rats

Accession no

Gene name

Function

Transport

Metabolism

$\begin{array}{ll} & \text { Al713204 } \\ & \text { NM_012497 } \\ & \text { NM_133298 } \\ & \text { NM_012580 } \\ & \text { NM_020308 } \\ & \\ & \text { D83508 } \\ & \text { BM388843 } \\ \text { Apoptosis } & \text { NM_012588 } \\ & \text { NM_022207 } \\ \text { Signal transduction } & \text { AA851740 } \\ \text { Response to stimulus } & \text { NM_012488 } \\ & \text { BI301490 } \\ \text { Homeostasis } & \text { NM_019232 } \\ & \text { J02582 } \\ & \text { BI277505 } \\ & \text { NM_031648 }\end{array}$

U13253

AA901341

$\mathrm{BI} 283882$

BI294137

Al713204
Fatty acid binding protein 5 , epidermal (Fabp5)

Solute carrier family 2 (facilitated glucose transporter), member 3 (Slc2a3)

Glucose phosphate isomerase (Gpi)

Hexokinase 2 (Hk2)

Monoglyceride lipase (Mgll)

Aldolase C, fructose-biphosphate (Aldoc)

Glycoprotein (transmembrane) nmb (Gpnmb)

Heme oxygenase (decycling) 1 (Hmox1)

A disintegrin and metalloproteinase domain 15 (metargidin;

Adam15)

Early growth response 2 (Egr2)

Tissue inhibitor of metalloproteinase 2 (Timp2)

Insulin-like growth factor binding protein 3 (Igfbp3)

Unc-5 homolog B (C. elegans; Unc5b)

Interleukin 6 signal transducer (II6st)

Alpha-2-macroglobulin (A2m)

Major histocompatibility complex, class II, DM alpha

Serum- and glucocorticoid-inducible kinase 1 (Sgk)

Apolipoprotein E (Apoe)

Phosphoglucomutase 1 (Pgm1)

FXYD domain-containing ion transport regulator 1 (Fxyd1)
Fold change

$1 \cdot 1$

$1 \cdot 4$

$1 \cdot 2$

$1 \cdot 3$

$1 \cdot 6$

$1 \cdot 4$

$1 \cdot 6$

$1 \cdot 4$

$1 \cdot 3$

$1 \cdot 4$

$1 \cdot 3$

$1 \cdot 4$

$1 \cdot 2$

$1 \cdot 2$

$1 \cdot 7$

$1 \cdot 5$

1.5

$1 \cdot 3$

$1 \cdot 2$
GK islets as compared with non-diabetic controls (Tables 8 and 12). Since cyclin D1 (X75207) is stimulated by known $\beta$-cell mitogens (Friedrichsen et al. 2006), it appears essential for postnatal $\beta$-cell growth (Kushner et al. 2005) and its overexpression increases human $\beta$-cell proliferation by tenfold (CozarCastellano et al. 2004); increase in D-type cyclin activity can be harnessed to advantage in promoting $\beta$-cell proliferation that is inadequate in islets from GK rats (Portha 2005) and type 2 diabetic patients (BonnerWeir \& Weir 2005; Butler et al. 2003). Caspase-6, involved in $\beta$-cell apoptosis (Thomas et al. 2001), was up-regulated in GK islets as compared with Wistar islets (Table 11). IGFBP-3 (NM_012588), recently proposed as a novel mediator of $\beta$-cell apoptosis (Shim et al. 2004), was up-regulated by high glucose (Table 9 ) and might contribute to $\beta$-cell glucoapoptosis. Apolipoprotein E (ApoE; J02582), a known constituent of islet amyloid deposits in both rodents and man (Powell et al. 2003), was up-regulated in GK islets (Table 7). ApoE (J02582) has been suggested to promote amyloidogenesis by stabilizing amyloid fibrils (Kahn et al. 1999), found in $90 \%$ of type 2 diabetic patients' post-mortem (Opie 1901) and also in GK islets (Leckstrom et al. 1996). An association between ApoE (J02582) gene polymorphisms and type 2 diabetes has also been noted (Vidal et al. 2003). It is thus possible that all these proteins up-regulated (caspase-6, IGFBP-3, and ApoE)

Table 10 Islet transcripts down-regulated by high versus low glucose in non-diabetic Wistar rats

Accession no

Gene name

Transducer of ERBB2, 1 (Tob1)

Kinesin light chain 3 (Klc3)

Cytochrome P450, subfamily 51 (Cyp51)

Eukaryotic translation initiation factor 2 alpha kinase 3 (Eif2ak3)

DNA primase, p49 subunit

Topoisomerase (DNA) 2 alpha (Top2a)

Fragile $\mathrm{X}$ mental retardation syndrome 1 homolog (Fmr1)

Single stranded DNA binding protein 3 (Ssdp3)

General transcription factor II I repeat domain-containing 1

(Gtf2ird1)

Forkhead box A3 (Foxa3)
Fold change

$1 \cdot 4$

$1 \cdot 4$

$1 \cdot 2$

$1 \cdot 2$

$1 \cdot 2$

$1 \cdot 4$

$1 \cdot 4$

$1 \cdot 4$

$1 \cdot 2$

$1 \cdot 2$ 
Table 11 Islet transcripts up-regulated in diabetic GK rats versus non-diabetic Wistar rats

Accession no

Gene name

Function

Transport

$\begin{array}{ll} & \text { AF202115 } \\ & \text { NM_053637 } \\ \text { Metabolism } & \text { AA943122 } \\ & \text { BI295900 } \\ & \text { NM_019383 } \\ & \\ & \text { AW528459 } \\ \text { Apoptosis } & \text { AF051335 } \\ & \text { NM_031775 } \\ \text { Signal transduction } & \text { NM_019191 } \\ & \text { NM_023950 } \\ & \text { NM_012823 } \\ \text { Development } & \text { AF236130 } \\ & \text { NM_017154 } \\ & \text { NM_057132 } \\ \text { Cell adhesion } & \text { BF398112 } \\ & \text { NM_031561 }\end{array}$
d (Atp5h)
Vesicle transport through interaction with t-SNAREs homolog $1 \mathrm{~A} \quad 1 \cdot 2$ (yeast; Vti1a)

Ceruloplasmin (Cp) $1 \cdot 3$

Syntaxin binding protein 3 (Stxbp3) $1 \cdot 2$

Transmembrane protein 9 (predicted; Tmem9_predicted) 1.2

Dihydrolipoamide S-acetyltransferase (E2 component of pyruvate $\quad 1.2$

dehydrogenase complex; Dlat)

ATP synthase, $\mathrm{H}+$ transporting, mitochondrial F0 complex, subunit $\quad 1 \cdot 1$

POU domain, class 2, transcription factor 1 (Pou2f1)

Reticulon 4 (Rtn4) $\quad 1.5$

Caspase 6 (Casp6) 1.2

MAD homolog 2 (Drosophila; Madh2) $1 \cdot 1$

RAB7, member RAS oncogene family (Rab7) $\quad 1 \cdot 1$

Annexin A3 (Anxa3) 1.4

Disabled homolog 2 (Drosophila) interacting protein (Dab2ip) $1 \cdot 2$

Xanthine dehydrogenase hypothetical gene (Xdh) 1.2

Ras homolog gene family, member A (Rhoa) $1 \cdot 2$

Smoothened homolog (Drosophila; Smo) 1.2

CD36 antigen (collagen type I receptor, thrombospondin receptor)- $\quad 1 \cdot 2$
Fold change

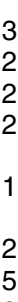

Table 12 Islet transcripts down-regulated in diabetic GK rats versus non-diabetic Wistar rats

Accession no

Gene name

Solute carrier family 29 (nucleoside transporters), member 2 (Slc29a2)

Eukaryotic translation elongation factor 2 (Eef2)

Eukaryotic translation initiation factor 2B, subunit 5 epsilon (Eif2b5)

Aldolase $\mathrm{C}$, fructose-biphosphate (Aldoc)

Phosphoglycerate kinase 1 (Pgk1)

Prostaglandin-endoperoxide synthase 2 (Ptgs2)

Protein kinase, AMP-activated, beta 2 non-catalytic subunit

(Prkab2)

Protein kinase, AMP-activated, beta 1 non-catalytic subunit

(Prkab1)

Acyl-CoA synthetase long-chain family member 4 (AcsI4)

NM_053623

NM_030997

BG378885

BM387190

NM_053826

AB020480

X75207

BE113385

NM_031138

Apoptosis

AW143805

Signal transduction

Al177031

NM_030846

Al103954

Cell adhesion

BM384639

NM_017190

NM_019329
VGF nerve growth factor inducible (Vgf)

High mobility group AT-hook 1 (Hmga1)

Transcription factor 19

Pyruvate dehydrogenase kinase 1 (Pdk1)

SNF1-like kinase (Snf1lk)

Cyclin D1 (Ccnd1)

Casein kinase 1, alpha 1 (Csnk1a1)

Ubiquitin-conjugating enzyme E2B, RAD6 homolog (S. cerevisiae;

Ube2b)

Guanine nucleotide binding protein, alpha q polypeptide (Gnaq) $\quad 1.4$

ER transmembrane protein Dri 42 (Ppap2b)

Growth factor receptor bound protein 2 (Grb2)

ADP-ribosylation factor-like 5 (Arl5)

Aggrecan 1 (Agc1)

Myelin-associated glycoprotein (Mag)

Contactin 3 (Cntn3)
Fold change

$1 \cdot 3$

$1 \cdot 1$

$1 \cdot 1$

$1 \cdot 2$

$1 \cdot 1$

$1 \cdot 6$

$1 \cdot 4$

$1 \cdot 1$

$1 \cdot 1$

$1 \cdot 7$

$1 \cdot 3$

$1 \cdot 3$

$1 \cdot 3$

$1 \cdot 2$

$1 \cdot 3$

$1 \cdot 1$

$1 \cdot 1$

$1 \cdot 4$

$1 \cdot 1$

$1 \cdot 4$

$1 \cdot 2$

$1 \cdot 4$ 
Table 13 Validation by qRT-PCR of glucose-regulated islet transcripts identified by microarray analysis

Gene name

Serum- and glucocorticoid-inducible kinase 1 (Sgk)

Apolipoprotein E (Apoe)

Insulin-like growth factor binding protein 3 (Igfbp3)

Insulin-2

Insulin-2

Insulin-2

Insulin-2

11ß-hydroxysteroid dehydrogenase type 1 (Hsd11b1)

Apolipoprotein E (Apoe)
Up-regulated by high versus low glucose in nondiabetic Wistar rats

Down-regulated by high versus low glucose in diabetic GK rats

Down-regulated by high glucose in diabetic GK rats versus high glucose in non-diabetic Wistar rats

Down-regulated by low glucose in diabetic GK rats versus low glucose in non-diabetic Wistar rats

Up-regulated by low glucose in diabetic GK rats versus low glucose in non-diabetic Wistar rats
$1 \cdot 71 \pm 0.5^{\star} \dagger$
$1 \cdot 11 \pm 0 \cdot 4^{\star} \dagger$
$2 \cdot 79 \pm 0 \cdot 4^{\star} \dagger$
$11 \cdot 70 \pm 1 \cdot 3^{\star}$
$0.60 \pm 4 \cdot 8^{*}, \dagger$
$0.02 \pm 0.4^{\star}, \dagger$
$0.32 \pm 0.1^{*} \dagger$
$1.73 \pm 0.4^{\star} \dagger$
$1.92 \pm 0.3^{\star} \dagger$

Results are means \pm S.E.M. of three experiments. *Denotes $P<0.05$ for a chance difference versus controls using Student's unpaired $t$-test. ${ }^{\dagger}$ Denotes correlation between microarray and qRT-PCR is significant at the $P<0.01$ level.

may contribute to the increased apoptosis known to occur in $\beta$-cells from GK rats (Koyama et al. 1998; Portha 2005) and patients with type 2 diabetes (Federici $e t$ al. 2001, Butler et al. 2003).

Expression of the glucose-dependent insulinotropic polypeptide receptor (GIPr; NM_012714) was approximately twofold lower in GK low glucose when compared with GK high glucose. This suggests a tonic reduction of incretin signaling in GK islets, potentially a major contributor to the islet defect in this diabetes model. Since the incretin signaling/sensing is an important physiologic regulator of glucose-stimulated insulin secretion and $\beta$-cell development, this impairment would be consistent with the reduced cyclin D1 (X75207) and increased apoptosis genes. The insulinotropic response to GIP (NM_012714) in $\beta$-cells is also grossly impaired in diabetic patients (Vilsboll et al. 2003).

Recent studies have suggested an inflammatory contribution to the pathogenesis of type 2 diabetes (Donath et al. 2005, Kolb \& Mandrup-Poulsen 2005, Homo-Delarche et al. 2006). Major histocompatibility complex, class II gene (MHC class II; AI171966, BI301490) is an immune gene associated with type 2 diabetes (Acton et al. 1994). This gene was up-regulated in GK islets when compared with Wistar islets at $3 \mathrm{mM}$ glucose and down-regulated by high glucose $(20 \mathrm{mM})$ in GK islets in our study (Tables 4 and 7).

As expected, the insulin gene was robustly up-regulated (11.7-fold) in response to high glucose in islets from nondiabetic rats (Table 13), whereas glucose failed to influence insulin gene expression in islets from GK rats. Similar results were obtained in Psammomysobesus, another animal model of type 2 diabetes, by Leibowitz et al. (2002). However, the insulin content was significantly higher in islets from diabetic rats when compared with normal rats, suggesting that glucose-induced proinsulin biosynthesis might predominantly be controlled at the translational level and also by stabilization of proinsulin mRNA rather than at the transcriptional level (Webb et al. 2000).

In conclusion, we identified significant changes in several islet mRNAs involved in glucose sensing, phosphorylation, incretin action, glucocorticoid handling, ion transport, mitogenesis, and apoptosis that clearly distinguish diabetic animals from controls. Such markers may provide clues to the pathogenesis of human type 2 diabetes and may be of predictive and therapeutical value in clinical settings in efforts aiming at conferring $\beta$-cell protection against apoptosis, impaired regenerative capacity, and functional suppression occurring in diabetes.

\section{Acknowledgements}

The skilful Affymetrix gene expression analyses kindly performed by Dr Bryan Burkey and Dr Daniel Kemp, Clinical Pharmacogenetics Department, Novartis Pharmaceuticals Corporation (Gaithersburg, MD, USA), is gratefully acknowledged. Financial support was received from the Swedish Medical Research Council, Petrus and Augusta Hedlund's Foundation, the Nutricia Research Foundation, the Swedish Society of Medicine, the Sigurd and Elsa Golje Memorial Foundation, Svenska Försäkringsföreningen, Svenska Diabetesstiftelsen, Magn. Bergvall Foundation, Barndiabetesfonden, Åke Wiberg's Foundation, Torsten and Ragnar Söderberg's Foundations, Berth von Kantzow's Foundation, and Research Center at Södersjukhuset, Stockholm. The authors declare that there is no conflict of interest that would prejudice the impartiality of this scientific work. 


\section{References}

Abdel-Halim SM, Guenifi A, Luthman H, Grill V, Efendic S \& Ostenson CG 1994 Impact of diabetic inheritance on glucose tolerance and insulin secretion in spontaneously diabetic GK-Wistar rats. Diabetes 43 281-288.

Acton RT, Roseman JM, Bell DS, Goldenberg RL, Tseng ML, Vanichanan C, Harman LA \& Go RC 1994 Genes within the major histocompatibility complex predict NIDDM in African-American women in Alabama. Diabetes Care 17 1491-1494.

Baldi P \& Long AD 2001 A Bayesian framework for the analysis of microarray expression data: regularized t-test and statistical inferences of gene changes. Bioinformatics 17 509-519.

Bonner-Weir S \& Weir GC 2005 New sources of pancreatic $\beta$-cells. Nature Biotechnology 23 857-861.

Briaud I, Kelpe CL, Johnson LM, Tran PO \& Poitout V 2002 Differential effects of hyperlipidemia on insulin secretion in islets of langerhans from hyperglycemic versus normoglycemic rats. Diabetes $51662-668$.

Butler AE, Janson J, Bonner-Weir S, Ritzel R, Rizza RA \& Butler PC $2003 \beta$-cell deficit and increased $\beta$-cell apoptosis in humans with type 2 diabetes. Diabetes 52 102-110.

Cao H, van der Veer E, Ban MR, Hanley AJ, Zinman B, Harris SB, Young TK, Pickering JG \& Hegele RA 2004 Promoter polymorphism in PCK1 (phosphoenolpyruvate carboxykinase gene) associated with type 2 diabetes mellitus. Journal of Clinical Endocrinology and Metabolism 89 898-903.

Carpenter L, Cordery D \& Biden TJ 2002 Inhibition of protein kinase C $\delta$ protects rat INS- 1 cells against interleukin- $1 \beta$ and streptozotocin-induced apoptosis. Diabetes 51 317-324.

Choe SE, Boutros M, Michelson AM, Church GM \& Halfon MS 2005 Preferred analysis methods for Affymetrix GeneChips revealed by a wholly defined control dataset. Genome Biology 6 R16.

Cnop M, Hannaert JC, Grupping AY \& Pipeleers DG 2002 Low density lipoprotein can cause death of islet $\beta$-cells by its cellular uptake and oxidative modification. Endocrinology 143 3449-3453.

Cozar-Castellano I, Takane KK, Bottino R, Balamurugan AN \& Stewart AF 2004 Induction of $\beta$-cell proliferation and retinoblastoma protein phosphorylation in rat and human islets using adenovirusmediated transfer of cyclin-dependent kinase- 4 and cyclin D1. Diabetes 53 149-159.

Davani B, Khan A, Hult M, Martensson E, Okret S, Efendic S, Jornvall H \& Oppermann UC 2000 Type $111 \beta$-hydroxysteroid dehydrogenase mediates glucocorticoid activation and insulin release in pancreatic islets. Journal of Biological Chemistry 275 34841-34844.

Davani B, Portwood N, Bryzgalova G, Reimer MK, Heiden T, Ostenson CG, Okret S, Ahren B, Efendic S \& Khan A 2004 Aged transgenic mice with increased glucocorticoid sensitivity in pancreatic $\beta$-cells develop diabetes. Diabetes 53 S51-S59.

Del Guerra S, Lupi R, Marselli L, Masini M, Bugliani M, Sbrana S, Torri S, Pollera M, Boggi U, Mosca F et al. 2005 Functional and molecular defects of pancreatic islets in human type 2 diabetes. Diabetes $\mathbf{5 4}$ $727-735$.

Donath MY, Ehses JA, Maedler K, Schumann DM, Ellingsgaard H, Eppler E \& Reinecke M 2005 Mechanisms of $\beta$-cell death in type 2 diabetes. Diabetes 54 S108-S113.

Duplomb L, Lee Y, Wang MY, Park BH, Takaishi K, Agarwal AK \& Unger RH 2004 Increased expression and activity of 11ß-HSD-1 in diabetic islets and prevention with troglitazone. Biochemical and Biophysical Research Communications 313 594-599.

Eitel K, Staiger H, Rieger J, Mischak H, Brandhorst H, Brendel MD, Bretzel RG, Haring HU \& Kellerer M 2003 Protein kinase C $\delta$ activation and translocation to the nucleus are required for fatty acidinduced apoptosis of insulin-secreting cells. Diabetes 52 991-997.

Federici M, Hribal M, Perego L, Ranalli M, Caradonna Z, Perego C, Usellini L, Nano R, Bonini P, Bertuzzi F et al. 2001 High glucose causes apoptosis in cultured human pancreatic islets of Langerhans: a potential role for regulation of specific Bcl family genes toward an apoptotic cell death program. Diabetes 50 1290-1301.

Fernandez-Mejia C, Medina-Martinez O, Martinez-Perez L \& Goodman PA 1999 The human insulin gene contains multiple transcriptional elements that respond to glucocorticoids. Pancreas 18 336-341.

Friedrichsen BN, Neubauer N, Lee YC, Gram VK, Blume N, Petersen JS, Nielsen JH \& Moldrup A 2006 Stimulation of pancreatic $\beta$-cell replication by incretins involves transcriptional induction of cyclin D1 via multiple signalling pathways. Journal of Endocrinology 188 481-492.

Goto Y, Kakizaki M \& Masaki N 1976 Production of spontaneous diabetic rats by repetition of selective breeding. Tohoku Journal of Experimental Medicine 119 85-90.

Goto Y, Suzuki K, Ono T, Sasaki M \& Toyota T 1988 Development of diabetes in the non-obese NIDDM rat (GK rat). Advances in Experimental Medicine and Biology 246 29-31.

Griffin E, Re A, Hamel N, Fu C, Bush H, McCaffrey T \& Asch AS 2001 A link between diabetes and atherosclerosis: glucose regulates expression of CD36 at the level of translation. Nature Medicine 7 840-846.

Guenifi A, Abdel-Halim SM, Hoog A, Falkmer S \& Ostenson CG 1995 Preserved $\beta$-cell density in the endocrine pancreas of young, spontaneously diabetic Goto-Kakizaki (GK) rats. Pancreas 10 148-153.

Gunton JE, Kulkarni RN, Yim S, Okada T, Hawthorne WJ, Tseng YH, Roberson RS, Ricordi C, O'Connell PJ, Gonzalez FJ et al. 2005 Loss of ARNT/HIF1 $\beta$ mediates altered gene expression and pancreatic-islet dysfunction in human type 2 diabetes. Cell 122 337-349.

Homo-Delarche F, Calderari S, Irminger JC, Gangnerau MN, Coulaud J, Rickenbach K, Dolz M, Halban P, Portha B \& Serradas P 2006 Islet inflammation and fibrosis in a spontaneous model of type 2 diabetes, the GK Rat. Diabetes 55 1625-1633.

Hoy M, Berggren PO \& Gromada J 2003 Involvement of protein kinase C- $\varepsilon$ in inositol hexakisphosphate-induced exocytosis in mouse pancreatic $\beta$-cells. Journal of Biological Chemistry 278 35168-35171.

Hughes SJ, Faehling M, Thorneley CW, Proks P, Ashcroft FM \& Smith PA 1998 Electrophysiological and metabolic characterization of single $\beta$-cells and islets from diabetic GK rats. Diabetes 47 73-81.

Ishihara H, Wada T, Kizuki N, Asano T, Yazaki Y, Kikuchi M \& Oka Y 1999 Enhanced phosphoinositide hydrolysis via overexpression of phospholipase $\mathrm{C} \beta 1$ or $\delta 1$ inhibits stimulus-induced insulin release in insulinoma MIN6 cells. Biochemical and Biophysical Research Communications 254 77-82.

Kahn SE, Andrikopoulos S \& Verchere CB 1999 Islet amyloid: a longrecognized but underappreciated pathological feature of type 2 diabetes. Diabetes 48 241-253.

Kato S, Ishida H, Tsuura Y, Tsuji K, Nishimura M, Horie M, Taminato T, Ikehara S, Odaka H, Ikeda I et al. 1996 Alterations in basal and glucose-stimulated voltage-dependent $\mathrm{Ca} 2+$ channel activities in pancreatic $\beta$ cells of non-insulin-dependent diabetes mellitus GK rats. Journal of Clinical Investigation 97 2417-2425.

Kimura K, Toyota T, Kakizaki M, Kudo M, Takebe K \& Goto Y 1982 Impaired insulin secretion in the spontaneous diabetes rats. Tohoku Journal of Experimental Medicine 137 453-459.

Kolb H \& Mandrup-Poulsen T 2005 An immune origin of type 2 diabetes? Diabetologia 48 1038-1050.

Koyama M, Wada R, Sakuraba H, Mizukami H \& Yagihashi S 1998 Accelerated loss of islet $\beta$ cells in sucrose-fed Goto-Kakizaki rats, a genetic model of non-insulin-dependent diabetes mellitus. American Journal Pathology 153 537-545.

Kushner JA, Ciemerych MA, Sicinska E, Wartschow LM, Teta M, Long SY, Sicinski P \& White MF 2005 Cyclins D2 and D1 are essential for postnatal pancreatic $\beta$-cell growth. Molecular and Cellular Biology 25 3752-3762.

Lambillotte C, Gilon P \& Henquin JC 1997 Direct glucocorticoid inhibition of insulin secretion. An in vitro study of dexamethasone effects in mouse islets. Journal of Clinical Investigation 99 414-423. 
Leckstrom A, Ostenson CG, Efendic S, Arnelo U, Permert J, Lundquist I \& Westermark P 1996 Increased storage and secretion of islet amyloid polypeptide relative to insulin in the spontaneously diabetic GK rat. Pancreas 13 259-267.

Leclerc I \& Rutter GA 2004 AMP-activated protein kinase: a new $\beta$-cell glucose sensor?: regulation by amino acids and calcium ions Diabetes 53 S67-S74.

Leibowitz G, Uckaya G, Oprescu AI, Cerasi E, Gross DJ \& Kaiser N 2002 Glucose-regulated proinsulin gene expression is required for adequate insulin production during chronic glucose exposure. Endocrinology 143 3214-3220.

Ling ZC, Khan A, Delauny F, Davani B, Ostenson CG, Gustafsson JA, Okret S, Landau BR \& Efendic S 1998 Increased glucocorticoid sensitivity in islet $\beta$-cells: effects on glucose 6-phosphatase, glucose cycling and insulin release. Diabetologia 41 634-639.

Ludvigsen E, Olsson R, Stridsberg M, Janson ET \& Sandler S 2004 Expression and distribution of somatostatin receptor subtypes in the pancreatic islets of mice and rats. Journal of Histochemistry and Cytochemistry 52 391-400.

MacDonald MJ 1990 Elusive proximal signals of $\beta$-cells for insulin secretion. Diabetes 39 1461-1466.

MacDonald PE \& Wheeler MB 2003 Voltage-dependent K(+) channels in pancreatic $\beta$ cells: role, regulation and potential as therapeutic targets. Diabetologia 46 1046-1062.

MacDonald MJ, McKenzie DI, Walker TM \& Kaysen JH 1992 Lack of glyconeogenesis in pancreatic islets: expression of gluconeogenic enzyme genes in islets. Hormone and Metabolic Research 24 158-160.

Malaisse WJ 1994 The $\beta$ cell in NIDDM: giving light to the blind. Diabetologia 37 S36-S42.

Mendez CF, Leibiger IB, Leibiger B, Hoy M, Gromada J, Berggren PO \& Bertorello AM 2003 Rapid association of protein kinase C- $\varepsilon$ with insulin granules is essential for insulin exocytosis. Journal of Biological Chemistry 278 44753-44757.

Mertz RJ, Worley JF, Spencer B, Johnson JH \& Dukes ID 1996 Activation of stimulus-secretion coupling in pancreatic $\beta$-cells by specific products of glucose metabolism. Evidence for privileged signaling by glycolysis. Journal of Biological Chemistry 271 4838-4845.

Metz SA, Meredith M, Vadakekalam J, Rabaglia ME \& Kowluru A 1999 A defect late in stimulus-secretion coupling impairs insulin secretion in Goto-Kakizaki diabetic rats. Diabetes 48 1754-1762.

Mutch DM, Berger A, Mansourian R, Rytz A \& Roberts MA 2002 The limit fold change model: a practical approach for selecting differentially expressed genes from microarray data. BMC Bioinformatics 317.

Nestorowicz A, Inagaki N, Gonoi T, Schoor KP, Wilson BA, Glaser B, Landau H, Stanley CA, Thornton PS, Seino S et al. 1997 A nonsense mutation in the inward rectifier potassium channel gene, Kir6.2, is associated with familial hyperinsulinism. Diabetes 46 1743-1748.

Nielsen DA, Welsh M, Casadaban MJ \& Steiner DF 1985 Control of insulin gene expression in pancreatic $\beta$-cells and in an insulinproducing cell line, RIN-5F cells. I. Effects of glucose and cyclic AMP on the transcription of insulin mRNA. Journal of Biological Chemistry 260 13585-13589.

Noushmehr H, D'Amico E, Farilla L, Hui H, Wawrowsky KA, Mlynarski W, Doria A, Abumrad NA \& Perfetti R 2005 Fatty acid translocase (FAT/CD36) is localized on insulin-containing granules in human pancreatic $\beta$-cells and mediates fatty acid effects on insulin secretion. Diabetes 54 472-481.

Ohneda M, Johnson JH, Inman LR, Chen L, Suzuki K, Goto Y, Alam T, Ravazzola M, Orci L \& Unger RH 1993 GLUT2 expression and function in $\beta$-cells of GK rats with NIDDM. Dissociation between reductions in glucose transport and glucose-stimulated insulin secretion. Diabetes 42 1065-1072.

Okajima F, Kurihara M, Ono C, Nakajima Y, Tanimura K, Sugihara H, Tatsuguchi A, Nakagawa K, Miyazawa T \& Oikawa S 2005 Oxidized but not acetylated low-density lipoprotein reduces preproinsulin mRNA expression and secretion of insulin from HIT-T15 cells. Biochimica et Biophysica Acta 1687 173-180.
Opie E 1901 The relation of diabetes mellitus to lesions of the pancreas: hyaline degeneration of the islets of Langerhans. Journal of Experimental Medicine 5 527-540.

Ortsater H, Alberts P, Warpman U, Engblom LO, Abrahmsen L \& Bergsten P 2005 Regulation of 11 $\beta$-hydroxysteroid dehydrogenase type 1 and glucose-stimulated insulin secretion in pancreatic islets of Langerhans. Diabetes/Metabolism Research and Reviews 21 359-366.

Ostenson CG, Khan A, Abdel-Halim SM, Guenifi A, Suzuki K, Goto Y \& Efendic S 1993 Abnormal insulin secretion and glucose metabolism in pancreatic islets from the spontaneously diabetic GK rat. Diabetologia 36 3-8.

Philippe J, Giordano E, Gjinovci A \& Meda P 1992 Cyclic adenosine monophosphate prevents the glucocorticoid-mediated inhibition of insulin gene expression in rodent islet cells. Journal of Clinical Investigation 90 2228-2233.

Portha B 2005 Programmed disorders of $\beta$-cell development and function as one cause for type 2 diabetes? The GK rat paradigm Diabetes/Metabolism Research and Reviews 21 495-504.

Portha B, Serradas P, Bailbe D, Suzuki K, Goto Y \& Giroix MH 1991 Beta-cell insensitivity to glucose in the GK rat, a spontaneous nonobese model for type II diabetes. Diabetes 40 486-491.

Powell DS, Maksoud H, Charge SB, Moffitt JH, Desai M, Da Silva Fihlo RL, Hattersley AT, Stratton IM, Matthews DR, Levy JC et al. 2003 Apolipoprotein E genotype, islet amyloid deposition and severity of type 2 diabetes. Diabetes Research and Clinical Practice 60 105-110.

Prentki M, Joly E, El-Assaad W \& Roduit R 2002 Malonyl-CoA signaling, lipid partitioning, and glucolipotoxicity: role in $\beta$-cell adaptation and failure in the etiology of diabetes. Diabetes 51 S405-S413.

Roche E, Assimacopoulos-Jeannet F, Witters LA, Perruchoud B, Yaney G, Corkey B, Asfari M \& Prentki M 1997 Induction by glucose of genes coding for glycolytic enzymes in a pancreatic $\beta$-cell line (INS-1). Journal of Biological Chemistry 272 3091-3098.

Sandler S, Andersson A \& Hellerstrom C 1987 Inhibitory effects of interleukin 1 on insulin secretion, insulin biosynthesis, and oxidative metabolism of isolated rat pancreatic islets. Endocrinology 121 1424-1431.

Seckl JR \& Walker BR 2001 Minireview: 11ß-hydroxysteroid dehydrogenase type $1-$ a tissue-specific amplifier of glucocorticoid action. Endocrinology 142 1371-1376.

Sener A, Malaisse-Lagae F, Ostenson CG \& Malaisse WJ 1993 Metabolism of endogenous nutrients in islets of Goto-Kakizaki (GK) rats. Biochemical Journal 296 329-334.

Shapiro AM, Lakey JR, Ryan EA, Korbutt GS, Toth E, Warnock GL, Kneteman NM \& Rajotte RV 2000 Islet transplantation in seven patients with type 1 diabetes mellitus using a glucocorticoid-free immunosuppressive regimen. New England Journal of Medicine 343 230-238.

Shim ML, Levitt Katz LE, Davis J, Dotzler WC, Cohen P \& Ferry RJ Jr 2004 Insulin-like growth factor binding protein-3 is a novel mediator of apoptosis in insulin-secreting cells. Growth Hormone and IGF Research 14 216-225.

da Silva Xavier G, Leclerc I, Varadi A, Tsuboi T, Moule SK \& Rutter GA 2003 Role for AMP-activated protein kinase in glucose-stimulated insulin secretion and preproinsulin gene expression. Biochemical Journal 371 761-774.

Sjoholm A 1997 Glucose stimulates islet $\beta$-cell mitogenesis through GTP-binding proteins and by protein kinase C-dependent mechanisms. Diabetes 46 1141-1147.

Sjoholm A 1998 Aspects of novel sites of regulation of the insulin stimulus-secretion coupling in normal and diabetic pancreatic islets. Endocrine 9 1-13.

Thomas F, Wu J, Contreras JL, Smyth C, Bilbao G, He J \& Thomas J 2001 A tripartite anoikis-like mechanism causes early isolated islet apoptosis. Surgery 130 333-338.

Tsuboi T, da Silva Xavier G, Leclerc I \& Rutter GA 2003 5'-AMPactivated protein kinase controls insulin-containing secretory vesicle dynamics. Journal of Biological Chemistry 278 52042-52051. 
Ullrich S, Berchtold S, Ranta F, Seebohm G, Henke G, Lupescu A, Mack AF, Chao CM, Su J, Nitschke R et al. 2005 Serum- and glucocorticoid-inducible kinase 1 (SGK1) mediates glucocorticoid-induced inhibition of insulin secretion. Diabetes $\mathbf{5 4}$ 1090-1099.

Wajngot A, Giacca A, Grill V, Vranic M \& Efendic S 1992 The diabetogenic effects of glucocorticoids are more pronounced in low- than in high-insulin responders. PNAS 89 6035-6039.

Varadi A, Molnar E, Ostenson CG \& Ashcroft SJ 1996 Isoforms of endoplasmic reticulum $\mathrm{Ca}(2+)$-ATPase are differentially expressed in normal and diabetic islets of Langerhans. Biochemical Journal 319 $521-527$.

Warwar N, Efendic S, Ostenson CG, Haber EP, Cerasi E \& Nesher R 2006 Dynamics of glucose-induced localization of PKC isoenzymes in pancreatic $\beta$-cells: diabetes-related changes in the GK rat. Diabetes 55 590-599.

Webb GC, Akbar MS, Zhao C \& Steiner DF 2000 Expression profiling of pancreatic $\beta$ cells: glucose regulation of secretory and metabolic pathway genes. PNAS 97 5773-5778.

Weinhaus AJ, Bhagroo NV, Brelje TC \& Sorenson RL 2000 Dexamethasone counteracts the effect of prolactin on islet function: implications for islet regulation in late pregnancy. Endocrinology 141 1384-1393.

Verkarre V, Fournet JC, de Lonlay P, Gross-Morand MS, Devillers M, Rahier J, Brunelle F, Robert JJ, Nihoul-Fekete C, Saudubray JM et al. 1998 Paternal mutation of the sulfonylurea receptor (SUR1) gene and maternal loss of 11 p15 imprinted genes lead to persistent hyperinsulinism in focal adenomatous hyperplasia. Journal of Clinical Investigation 102 1286-1291.

Vidal J, Verchere CB, Andrikopoulos S, Wang F, Hull RL, Cnop M, Olin KL, LeBoeuf RC, O'Brien KD, Chait A et al. 2003 The effect of apolipoprotein $\mathrm{E}$ deficiency on islet amyloid deposition in human islet amyloid polypeptide transgenic mice. Diabetologia 46 71-79.

Vilsboll T, Knop FK, Krarup T, Johansen A, Madsbad S, Larsen S, Hansen T, Pedersen O \& Holst JJ 2003 The pathophysiology of diabetes involves a defective amplification of the late-phase insulin response to glucose by glucose-dependent insulinotropic polypeptide-regardless of etiology and phenotype. Journal of Clinical Endocrinology and Metabolism 88 4897-4903.

Yao B, Rakhade SN, Li Q, Ahmed S, Krauss R, Draghici S \& Loeb JA 2004 Accuracy of cDNA microarray methods to detect small gene expression changes induced by neuregulin on breast epithelial cells. BMC Bioinformatics 599.

Zhou YP, Ostenson CG, Ling ZC \& Grill V 1995 Deficiency of pyruvate dehydrogenase activity in pancreatic islets of diabetic GK rats. Endocrinology 136 3546-3551.

Zimmet P, Alberti KG \& Shaw J 2001 Global and societal implications of the diabetes epidemic. Nature 414 782-787.

Received in final form 5 June 2007

Accepted 12 June 2007

Made available online as an Accepted Preprint 14 June 2007 